\title{
Pertumbuhan Ekonomi Provinsi Kepulauan Riau
}

\author{
Elvina Safitri \\ STKIP YPM Bangko \\ E-mail: elvinasafitri87@gmail.com
}

\begin{abstract}
Abstrack: Economic growth as a quantitative measure that describes the development of an economy in a given year when compared with the previous year. Economic growth means the development of economic activities that cause goods and services produced in the community to increase and the welfare of society increases. Each region seeks to increase economic growth and stability, one of which is Riau Islands Province. To see how the economic growth of Riau Islands Province, then conducted a study entitled Economic Growth Riau Islands Province. The data source used is secondary data with descriptive data analysis method. From the analysis, it is known that the economic growth of Kepulauan Riau Province in the year of 2016 is 5.03\% with the highest growth rate in the big and retail trade, car and motorcycle repairs $9.54 \%$.
\end{abstract}

Keywords: Economic growth

\begin{abstract}
Abstrak: Pertumbuhan ekonomi sebagai suatu ukuran kuantitatif yang menggambarkan perkembangan suatu perekonomian dalam suatu tahun tertentu apabila dibandingkan dengan tahun sebelumnya. Pertumbuhan ekonomi berarti perkembangan kegiatan perekonomian yang menyebabkan barang dan jasa yang diproduksikan dalam masyarakat bertambah dan kemakmuran masyarakat meningkat. Setiap daerah berusaha meningkatkan pertumbuhan dan stabilitas ekonomi salah satunya daerah Provinsi Kepulauan Riau. Untuk melihat bagaimana pertumbuhan ekonomi Provinsi Kepulauan Riau, maka dilakukan penelitian yang berjudul Pertumbuhan Ekonomi Provinsi Kepulauan Riau. Sumber data yang digunakan adalah data sekunder dengan analisa data metode deskriptif. Dari hasil analisis diketahui bahwa pertumbuhan ekonomi Provinsi Kepulauan Riau Pada Tahun 2016 adalah sebesar 5,03 \% dengan nilai pertumbuhan tertinggi terdapat pada sektor perdagangan besar dan eceran, reparasi mobil dan sepeda motor sebanyak $9,54 \%$.
\end{abstract}

Kata Kunci: Pertumbuhan ekonomi

UTILITY: Jurnal IImiah Pendidikan dan Ekonomi

Website : http://journal.stkipnurulhuda.ac.id/index.php/utility

Permalink: https://journal.stkipnurulhuda.ac.id/index.php/utility/article/view/284

How to cite (APA): Safitri, E. (2018, February 1). Pertumbuhan Ekonomi Provinsi Kepulauan Riau. UTILITY: Jurnal IImiah Pendidikan Dan Ekonomi, 2(1), 52-65.

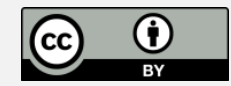

This is an open access article distributed under the terms of the Creative Commons Attribution 4.0 International License, which permits unrestricted use, distribution, and reproduction in any medium, provided the original work is properly cited. 


\section{PENDAHULUAN}

Pembangunan secara umumnya lebih bertumpu pada aspek ekonomi yang mana laju pertumbuhan ekonomi merupakan salah satu prasyarat untuk melakukan pembangunan pada aspek lainnya. Apalagi setelah diberlakukan Undang-Undang No.22 Tahun 1999 tentang otonomi daerah yang mengakibatkan tiap-tiap daerah berusaha untuk meningkatkan pertumbuhan dan pembangunan ekonomi daerah sendiri. Pembangunan ekonomi daerah adalah suatu proses dimana pemerintah daerah dan masyarakatnya mengelola sumber daya yang ada dan membentuk suatu pola kemitraan antara pemerintah daerah dengan sektor swasta untuk menciptakan suatu lapangan kerja baru dan merangsang perkembangan ekonomi (pertumbuhan ekonomi) dalam wilayah tersebut (Arsyad, 1999). Pertumbuhan ekonomi berarti perkembangan kegiatan perekonomian yang menyebabkan barang dan jasa yang diproduksikan dalam masyarakat bertambah dan kemakmuran masyarakat meningkat.

Provinsi Kepulauan Riau salah satu Provinsi dari Negara kesatuan Republik Indonesia yang berusaha meningkatkan pertumbuhan dan stabilitas ekonomi daerahnya. Bila diamati pertumbuhan dan perkembangan ekonomi di daerah Provinsi Kepulauan Riau boleh dikatakan cukup baik. Hal ini dikarenakan pertumbuhan ekonomi di daerah Kepulauan Riau dari tahun ke tahun kebelakang selalu mengalami peningkatan. Hal tersebut dapat dilihat pada tabel 1 Produk Domestik Regional Bruto Atas Dasar Harga Konstan 2010 Menurut Kabupaten/Kota di Provinsi Kepulauan Riau

Tabel 1. Produk Domestik Regional Bruto Atas Dasar Harga Konstan 2010 Kabupaten / Kota di Provinsi Kepulauan Riau (miliar rupiah) 2013-2016

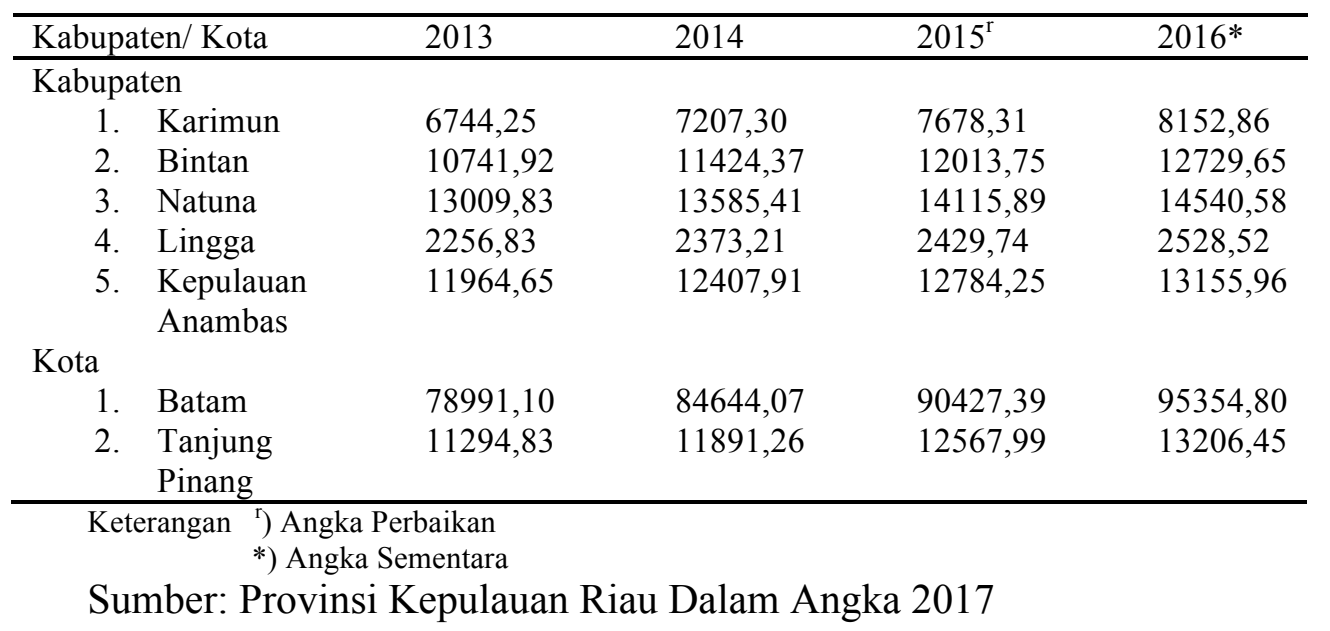


Pada tabel 1 di atas dapat dilihat perkembangan PDRB Kabupaten/Kota Provinsi Riau dari tahun ke tahun, dimana setiap tahunnya selalu meningkat. Pada tahun 2013 PDRB terbanyak adalah Kota Batam sebesar 78991,10 kemudian Kabupaten Natuna 13009,83 dilanjutkan oleh Kabupaten Kepulauan Anambas 11964,65, disusul oleh Kota Tanjungpinang 11294,83, Bintan 10741,92, Kabupaten Karimun 6744,25 dan Kabupaten Lingga 2256,83. Pada tahun 2014 PDRB tertinggi adalah Kota Batam sebanyak 84644,07, lalu Kabupaten Natuna 13585,41, kemudian Kepulauan Anambas 12407,91, Kota Tanjungpinang 11891,26, Kabupaten Bintan 11424,37, Kabupaten Karimun 7207,30 dan Kabupaten Lingga 2373,21. Pada tahun 2015 PDRB terbanyak, yaitu Kota Batam sebesar 90427,39, kemudian Kabupaten Natuna 14115,89, dilanjutkan Kepulauan Anambas 12784,25, lalu Kota Tanjungpinang 12567,99, Kabupaten Bintan 12013,75, Kabupaten Karimun 7678,31 dan Kabupaten Lingga 2429,74. Sedangkan Pada tahun 2016 PDRB terbanyak masih dipegang oleh Kota Batam sebesar 95354,80, lalu Kabupaten Natuna 14540,58, setelah itu Kota Tanjungpinang 13206,45, Kabupaten Kepulauan Anambas 13155,96, Kabupaten Bintan 12729,65, Kabupaten Karimunn 8152,86 dan Kabupaten Lingga 2528,52.

Dari penjelasan tersebut tampak perbedaan pendapatan antar wilayah berarti tidak samanya kemampuan untuk bertumbuh. Hal itu tentu akan mempengaruhi perekonomian Provinsi Kepulauan Riau. Berdasarkan latar belakang ini, maka penulis ingin melihat laju ekonomi Provinsi Riau dengan mengambil judul Pertumbuhan Ekonomi Provinsi Kepulauan Riau.

\section{METODE}

Sumber data yang diperlukan dalam penelitian ini adalah jenis data sekunder yaitu data yang diperoleh dari dokumentasi, laporan tahunan yang telah ditulis atau digambarkan yang erat hubungannya dengan penelitian ini. Adapun analisa data yang digunakan adalah analisa dengan metode deskriptif, sehingga dapat diketahui Pertumbuhan Ekonomi Provinsi Kepulauan Riau. 


\section{HASIL DAN PEMBAHASAN}

\section{Lokasi Penelitian}

Provinsi Kepulauan Riau memiliki luas wilayah sebesar $8.201,72 \mathrm{Km}^{2}$ terdiri dari daerah daratan dan perairan yang mana sekitar $96 \%$ merupakan lautan dan $4 \%$ daratan. Di daerah perairan terdapat 2408 pulau besar dan kecil yang mana $30 \%$ belum bernama dan berpenduduk. Provinsi Kepulauan Riau terletak antara $00^{\circ} 29^{\prime}$ Lintang Selatan dan 04 $40^{\prime}$ Lintang Utara serta antara $103^{\circ} 22^{\prime}$ Bujur Timur sampai dengan 1094' Bujur Timur. Adapun batas wilayah Provinsi Kepulauan Riau yaitu :

Batas Utara : Vietnam dan Kamboja

Batas Selatan : Sumatera Selatan dan Jambi

Batas Barat : Singapura, Malaysia dan Provinsi Riau

Batas Timur : Malaysia dan Kalimantan

Provinsi Kepulauan Riau terdiri dari lima Kabupaten dan dua kota. Adapun luas Kabupaten/ Kota Provinsi Kepualauan Riau berdasarkan Peraturan Menteri Dalam Negeri No.56 Tahun 2015 adalah sebagai berikut :

1. Karimun $(912,75 \mathrm{Km} 2)$

2. Bintan (1.318,21 Km2),

3. Natuna $(2.009,04 \mathrm{Km} 2)$,

4. Lingga (2.266,77 Km2),

5. Kepulauan Anambas (590,14 Km2)

6. Kota Batam $(960,25 \mathrm{Km} 2)$

7. Kota Tanjungpinang $(144,56 \mathrm{Km} 2)$

Jumlah penduduk Provinsi Kepulauan Riau pada tahun 2016 adalah sebanyak 2.028.169 jiwa yang terdiri atas 1.035.511 jiwa penduduk laki-laki dan 992.658 jiwa penduduk perempuan.

\section{Pertumbuhan Ekonomi Provinsi Kepulauan Riau}

Pembangunan ekonomi daerah Kepulauan Riau dimaksudkan untuk mendorong pertumbuhan ekonomi daerah yang cukup tinggi dan sekaligus menciptakan struktur ekonomi daerah yang berimbang dan beragam. Dengan 
ketahanan ekonomi daerah akan semakin tangguh dalam menghadapi berbagai tantangan baik yang bersumber daari dalam negeri maupun luar negeri.

Pertumbuhan ekonomi bisa dihitung dengan cara melihat laju pertumbuhan per tahun dimana laju pertumbuhan tersebut diperoleh dengan cara membandingkan Produk Domestik Regional Bruto pada tahun tertentu dengan Produk Domestik Regional Bruto pada tahun sebelumnya, dengan formula sebagai berikut ( Deliarnov,1995)

$$
\mathrm{G}=\frac{\mathrm{PDRB}_{1}}{\mathrm{PDRB}_{0}} \frac{-\mathrm{PDRB}_{0}}{\mathrm{~PB}_{0}} \times 100 \%
$$

Dimana :

$\mathrm{G}=$ Laju pertumbuhan (rate of growth)

$\mathrm{PDRB}_{1}=$ Produk Domestik Regional Bruto pada tahun tertentu

$\mathrm{PDRB}_{0}=$ Produk Domestik Regional Bruto pada tahun sebelumnya

Untuk mengetahui lebih lanjut tentang pertumbuhan ekonomi Provinsi Kepulauan Riau berikut ini akan disajikan tabel PDRB tahun 2015-2016 atas dasar harga konstan 2010 menurut lapangan usaha

Tabel 2. Produk Domestik Regional Bruto Atas Dasar Harga Konstan 2010 Menurut Lapangan Usaha di Provinsi Kepulauan Riau (miliar rupiah) 2015-2016

\begin{tabular}{|l|r|r|}
\hline \multicolumn{1}{|c|}{ Lapangan Usaha } & $2015^{\mathrm{r}}$ & \multicolumn{1}{|c|}{$2016^{*}$} \\
\hline A. Pertanian, Kehutanan dan Perikanan & 5689,22 & 5977,99 \\
\hline 1. Pertanian, Peternakan, Perburuan dan jasa Pertanian & 1883,40 & 1898,63 \\
\hline a. Tanaman Pangan & 22,37 & 23,26 \\
\hline b.Tanaman Hortikultura & 204,79 & 201,06 \\
\hline c.Perkebunan & 1098,98 & 1074,09 \\
\hline d.Peternakan & 514,43 & 557,05 \\
\hline e.Jasa Pertanian dan Perburuan & 42,83 & 43,18 \\
\hline 2. Kehutanan dan Penebangan Kayu & 38,26 & 37,49 \\
\hline 3. Perikanan & 3767,56 & 4041,88 \\
\hline B. Pertambangan dan Penggalian & 25417,33 & 26933,15 \\
\hline 1. Pertambangan Minyak dan Gas & 21975,01 & 23483,41 \\
\hline
\end{tabular}




\begin{tabular}{|c|c|c|}
\hline Lapangan Usaha & $2015^{\mathrm{r}}$ & $2016^{*}$ \\
\hline 2. Pertambangan Batubara dan Lignit & - & - \\
\hline 3. Pertambangan Bijih Logam & 2404,65 & 2450,75 \\
\hline 4. Pertambangan dan Penggalian Lainnya & 1037,67 & 999,00 \\
\hline C. Industri Pengolahan & 59498,19 & 61497,86 \\
\hline 1. Industri Batubara dan Pengilangan Migas & 1623,69 & 1646,28 \\
\hline 2. Industri Makanan dan Minuman & 1052,97 & 1182,18 \\
\hline 3. Pengolahan Tembakau & 280,45 & 260,84 \\
\hline 4. Industri Tekstil dan Pakaian Jadi & 1385,66 & 1437,20 \\
\hline 5. Industri Kulit, Barang dari Kulit dan Alas Kaki & 94,95 & 91,07 \\
\hline $\begin{array}{l}\text { 6. Industri Kayu, Barang dari Kayu dan Gabus } \\
\text { dan Barang Anyaman dari Bambu, Rotan dan } \\
\text { Sejenisnya }\end{array}$ & 721,92 & 678,49 \\
\hline $\begin{array}{l}\text { 7. Industri Kertas dan Barang dari Kertas, } \\
\text { Percetakan dan Reproduksi Media Rekamana }\end{array}$ & 372,95 & 348,56 \\
\hline 8. Industri Kimia, Farmasi dan Obat Tradisional & 367,07 & 390,05 \\
\hline 9. Industri Karet, Barang dari Karet dan Plastik & 2275,91 & 2185,99 \\
\hline 10. Industri Barang Galian bukan Logam & 175,18 & 178,13 \\
\hline 11. Industri Logam Dasar & 9031,36 & 9011,97 \\
\hline $\begin{array}{l}\text { 12. Industri Barang dari Logam, Komputer, Barang } \\
\text { Elektronik, Optik dan Peralatan Listrik }\end{array}$ & 29862,07 & 31218,86 \\
\hline 13. Industri Mesin dan Perlengkapan YTDL & 3333,50 & 3490,59 \\
\hline 14. Industri Alat Angkutan & 4623,99 & 4884,17 \\
\hline 15. Industri Furnitur & 1404,16 & 1488,32 \\
\hline $\begin{array}{l}\text { 16. Industri Pengolahan Lainnya, Jasa Reparasi dan } \\
\text { Pemasangan Mesin dan Peralatan }\end{array}$ & 2892,37 & 3005,17 \\
\hline D. Pengadaan Listrik dan Gas & 1400,52 & 1523,11 \\
\hline 1. Ketenagalistrikan & 318,91 & 400,36 \\
\hline 2. Pengadaan Gas dan Produksi Es & 1081,60 & 1122,74 \\
\hline $\begin{array}{l}\text { E. Pengadaan Air, Pengelolaan Sampah, Limbah dan } \\
\text { Daur Ulang }\end{array}$ & 193,11 & 203,26 \\
\hline F. Konstruksi & 26871,95 & 28073,93 \\
\hline $\begin{array}{l}\text { G. Perdagangan Besar dan Eceran, dan Reparasi Mobil } \\
\text { dan Sepeda motor }\end{array}$ & 11738,60 & 12858,55 \\
\hline $\begin{array}{l}\text { 1. Perdagangan Mobil, Sepeda Motor dan } \\
\text { Reparasinya }\end{array}$ & 4607,77 & 4748,66 \\
\hline
\end{tabular}




\begin{tabular}{|c|c|c|}
\hline Lapangan Usaha & $2015^{r}$ & $2016^{*}$ \\
\hline $\begin{array}{ll}\text { 2. } & \text { Perdagangan Besar dan Eceran Bukan Mobil } \\
& \text { dan Sepeda Motor }\end{array}$ & 7130,83 & 8109,89 \\
\hline H. Transportasi dan Pergudangan & 4161,12 & 4448,87 \\
\hline 1. $\quad$ Angkutan Rel & - & - \\
\hline 2. Angkutan Darat & 642,32 & 681,48 \\
\hline 3. Angkutan Laut & 1366,73 & 1454,28 \\
\hline 4. Angkutan Sungai Danau dan Penyeberangan & 6,74 & 7,26 \\
\hline 5. $\quad$ Angkutan Udara & 1896,20 & 2043,23 \\
\hline $\begin{array}{l}\text { 6. Pergudangna dan Jasa Penunjang Angkutan, } \\
\text { Pos dan Kurir }\end{array}$ & 249,13 & 262,62 \\
\hline I. $\quad$ Penyediaan Akomodasi dan Makan Minum & 3002,93 & 3159,14 \\
\hline 1. Penyediaan Akomodasi & 1502,63 & 1559,04 \\
\hline 2. Penyediaan Makan dan Minum & 1500,29 & 1600,11 \\
\hline J. Informasi dan Komunikasi & 3230,70 & 3469,62 \\
\hline K. Jasa Keuangan dan Asuransi & 4087,05 & 4323,70 \\
\hline 1. Jasa Perantara Keuangan & 2177,88 & 2361,48 \\
\hline 2. Asuransi dan Dana Pensiun & 1867,98 & 1917,75 \\
\hline 3. Jasa Keuangan Lainnya & 24,62 & 26,51 \\
\hline 4. Jasa Penunjnag Keuangan & 16,58 & 17,96 \\
\hline L. Real Estate & 2340,43 & 2443,35 \\
\hline M,N. Jasa Perusahaan & 7,80 & 8,28 \\
\hline $\begin{array}{l}\text { O. Administrasi Pemerintahan, Pertahanan dan } \\
\text { Jaminan Sosial Wajib }\end{array}$ & 3386,49 & 3619,47 \\
\hline P. Jasa Pendidikan & 2022,48 & 2201,37 \\
\hline Q. Jasa Kesehatan dan Kegiatan Sosial & 1405,32 & 1467,87 \\
\hline R,S,T,U. Jasa Lainnya & 659,67 & 712,98 \\
\hline Produk Domestik Regional Bruto & 155112,88 & 162922,50 \\
\hline
\end{tabular}

Keterangan : ${ }^{r}$ ) Angka Perbaikan

$$
\text { *) Angka Sementara }
$$

Sumber : Provinsi Kepulauan Riau Dalam Angka 2017

Dari tabel di atas dapat dilihat PDRB Provinsi Kepulauan Riau tahun 2015 adalah sebesar 155. 112,88 dan pada tahun 2016 sebesar 162. 922,50. Dari PDRB tersebut dapat diketahui laju pertumbuhan Provinsi Kepulauan Riau pada tahun 2016 yaitu : 


$$
\begin{aligned}
& G=\frac{162.922,50-155.122,88}{155.122,88} \quad \times 100 \% \\
& G=5,03 \%
\end{aligned}
$$

Dengan demikian pertumbuhan ekonomi Provinsi Kepulauan Riau tahun 2016 adalah sebesar 5,03\%. Sedangkan pertumbuhan masing-masing sektor tahun 2016 sebagai berikut :

a. Pertanian, Kehutanan dan Perikanan

$$
\begin{aligned}
& G=\frac{5.977,99-5.689,22}{5.689,22} \quad x 100 \% \\
& G=5,08 \%
\end{aligned}
$$

b. Pertambangan dan Penggalian

$$
\begin{aligned}
& \mathrm{G}=\frac{26.933,15-25.417,33}{25.417,33} \quad \times 100 \% \\
& \mathrm{G}=5,96 \%
\end{aligned}
$$

c. Industri Pengolahan

$$
\begin{aligned}
& \mathrm{G}=\frac{61.497,86-59.498,19}{59.498,19} \times 100 \% \\
& \mathrm{G}=3,36 \%
\end{aligned}
$$

d. Pengadaan Listik dan Gas

$$
\begin{aligned}
& G=\frac{1.523,11-1.400,52}{1.400,52} \quad \times 100 \% \\
& G=8,75 \%
\end{aligned}
$$

e. Pengadaan Air, Pengelolaan Sampah,Limbah dan Daur Ulang

$$
\begin{aligned}
& \mathrm{G}=\frac{203,26-193,11}{193,11} \times 100 \% \\
& \mathrm{G}=5,26 \%
\end{aligned}
$$

f. Konstruksi

$$
\begin{aligned}
& \mathrm{G}=\frac{28.073,93-26.871,95}{26.871,95} \times 100 \% \\
& \mathrm{G}=4,47 \%
\end{aligned}
$$


g. Perdagangan Besar dan Eceran, dan Reparasi Mobil dan Sepeda Motor

$$
\begin{aligned}
G & =\frac{12.858,55-11.738,60}{11.738,60} \quad \times 100 \% \\
G & =9,54 \%
\end{aligned}
$$

h. Transportasi dan Pergudangan

$$
\begin{aligned}
& \mathrm{G}=\frac{4.448,87-4 \cdot 161,12}{4 \cdot 161,12} \times 100 \% \\
& \mathrm{G}=6,92 \%
\end{aligned}
$$

i. Penyediaan Akomodasi dan Makan Minum

$$
\begin{aligned}
& G=\frac{3 \cdot 159,14-3.002,93}{3.002,93} \quad \times 100 \% \\
& G=5,20 \%
\end{aligned}
$$

j. Informasi dan Komunikasi

$$
\begin{aligned}
& \mathrm{G}=\frac{3.469,62-3.230,70}{3.230,70} \quad \times 100 \% \\
& \mathrm{G}=7,40 \%
\end{aligned}
$$

k. Jasa Keuangan dan Asuransi

$$
\begin{aligned}
& \mathrm{G}=\frac{4.323,70-4.087,05}{4.087,05} \times 100 \% \\
& \mathrm{G}=5,79 \%
\end{aligned}
$$

1. Real Estate

$$
\begin{aligned}
\mathrm{G} & =\frac{2.443,35-2.340,43}{2.340,43} \times 100 \% \\
\mathrm{G} & =5,03 \% \\
\mathrm{~m}, \mathrm{n} \text { Jasa Perusahaan } & \\
\mathrm{G} & =\frac{8,28-7,80}{7,80} \times 100 \% \\
\mathrm{G} & =6,15 \%
\end{aligned}
$$




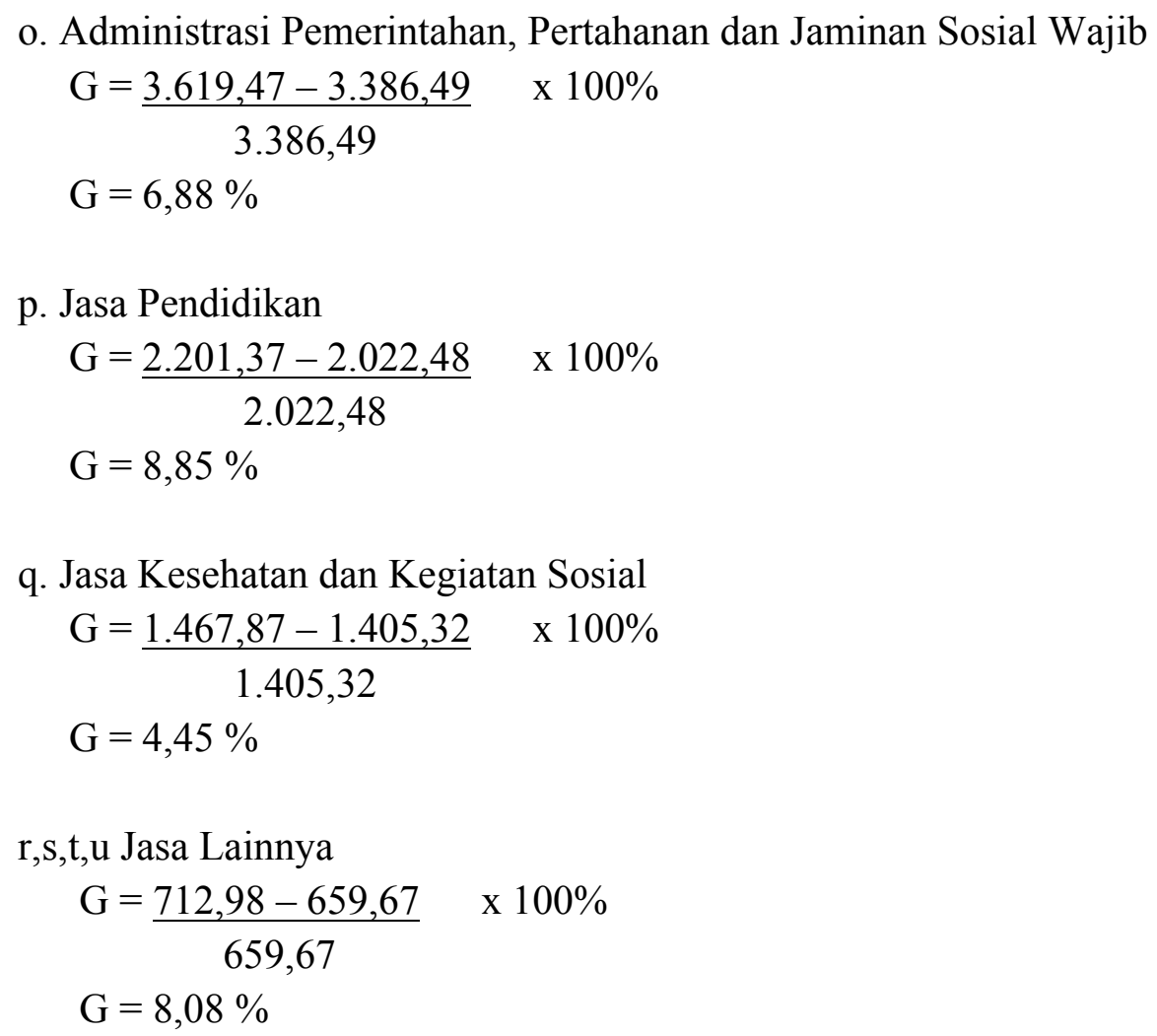

Dari perhitungan di atas dapat diketahui bahwa pertumbuhan tahun 2016 masing-masing sektor antara lain (a) pertanian, kehutanan dan perikanan 5,08 $\%$, (b) pertambangan dan penggalian 5,08 \%, (c) industri pengolahan 3,36\%, (d) pengadaan listrik dan gas $8,75 \%$, (e) pengadaan air, pengelolaan sampah, limbah dan daur ulang 5,26\%, (f) konstruksi 4,47\%, (g) perdagangan besar dan eceran, reparasi mobil dan sepeda motor 9,54\%, (h) transportasi dan pergudangan $6,92 \%$, (i) penyediaan akomodasi dan makan minum 5,20\%, (j) informasi dan komunikasi 7,40 5, (k) jasa keuangan dan asuransi 5,79 \%, (1) real estate 5,03 \%, (m,n) jasa perusahaan 6,15\%, (o) administrasi pemerintahan,pertahanan dan jaminan sosial wajib 6,88 \%, (p) jasa pendidikan $8,85 \%$, (q) jasa kesehatan dan kegiatan sosial 4,45\%,(r,s,t,u) jasa lainnya 8,08\%. 


\section{SIMPULAN}

Berdasarkan uraian di atas dapat disimpulkan bahwa laju pertumbuhan Provinsi Kepulauan Riau pada tahun 2016 yaitu sebesar 5,03 \% dengan pertumbuhan sektor peringkat 10 tertinggi terdapat pada (1) perdagangan besar dan eceran, reparasi mobil dan sepeda motor sebanyak 9,54\%, kemudian (2) jasa pendidikan $8,85 \%$, (3) pengadaan listrik dan gas $8,75 \%$, (4) jasa lainnya $8,08 \%,(5)$ informasi dan komunikasi $7,40 \%$, (6) transportasi dan pergudangan $6,92 \%,(7)$ administrasi pemerintahan pertahanan dan jaminan sosial wajib $6,88 \%$, (8) jasa perusahaan $6,15 \%$, (9) pertambangan dan penggalian 5,96\% serta (10) jasa keuangan dan auransi 5,79\%.

\section{SARAN}

Diharapkan pemerintah dan pihak terkait lainnya dapat lebih memperhatikan perkembangan dan keadaan tiap sektor di Provinsi Kepulauan Riau. Pemerintah harus cepat mengambil sikap bila ada sesuatu hal yang akan berdampak negatif atau yang tidak diinginkan pada setiap sektor. Jika pemerintah serta pihak terkait lainnya kurang memperhatikan hal yang terjadi pada tiap sektor, maka dapat mengakibatkan penurunan laju pertumbuhan ekonomi.

\section{REFERENSI}

Arsyad, L. (1999). Pengantar Perencanaan dan Pembangunan Ekonomi Daerah. Yogyakarta: BPFE-UGM.

BPS. (2017). Provinsi Kepulauan Riau Dalam Angka, 2017. Badan Pusat Statistik Provinsi Kepulauan Riau.

Deliarnov. (1995). Pengantar Ekonomi Makro, Jakarta, UI (UI-Press).

Ma'ruf, A., \& Wihastuti, L. (2008). Pertumbuhan ekonomi indonesia: determinan dan prospeknya. JESP: Jurnal Ekonomi \& Studi Pembangunan, 9(1), 44-55.

Nasution, A.P. (2012). Profil Provinsi Kepulauan Riau. Di akses: http://adenasution.com/2012/05/29/profil-provinsi-kepulauan-riau 
Rufaidah, E. (2015). Ilmu Ekonomi. Yogyakarta: Graha Ilmu.

Sukirno, S. (2007). Ekonomi Pembangunan: Poses Masalah dan Dasar Kebijakan. Jakarta: Kencana.

Sun'an, M. (2015). Ekonomi Pembangunan. Jakarta: Mitra Wacana Media.

Tan, S. (2012). Perencanaan Pembangunan. Jambi: Fakultas Ekonomi Universitas Jambi. 